\title{
Языковые установки и языковая лояльность носителей малых языков в условиях национально-русского двуязычия (на примере бурят и тувинцев)"
}

\author{
Галина А. Дырхеева, Чечек С. Цыбенова
}

Институт монголоведения, буддологии и тибетологии СО РАН, Российская Федерация

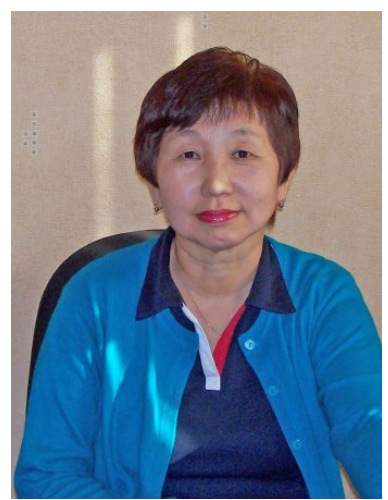

В статье анализируются языковые установки и ориентации современных носителей бурятского и тувинского языков в России (в Республике Бурятия и Республике Тыва). Необходимость профессиональной и культурной интеграции носителей малых языков в общероссийское и мировое пространство сегодня постепенно приводит к трансформации этноязыкового сознания.

Эмпирическая база исследования основывается на результатах комплексных социолингвистических обследований, проведенных в Бурятии в 1999-2000 г2. и Туве в 2009-2010 г2. с использованием единой методики. Впервые проводится сопоставительный анализ языковых ситуаций в указанных регионах.

Анализ оценочных параметров языковых ситуаций в Бурятии и Туве выявил, что на языковую лояльность и языковые установки огромное влияние оказывает демографически и функционально доминирующий русский язык. В условиях национально-русского двуязычия носители малых языков выбирают стратегию символизации родного языка. Этот факт косвенно подтверждает трансформацию языкового сознания малых народов. Указанная

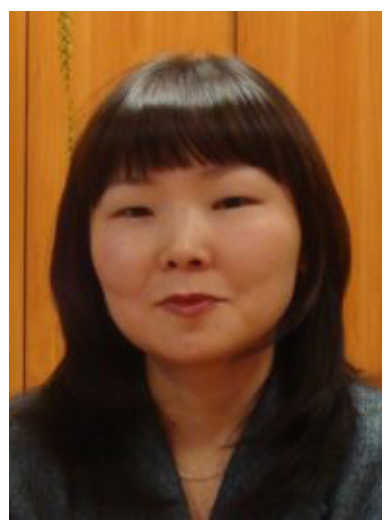
стратегия вероятно также обусловлена адаптационными механизмами, вызванными новыми социильно-экономическими условиями, информатизацией, технологизацией современного общества. Выявленная стратегия символизаиии свидетельствует о том, что пока русский язык для большинства носителей бурятского и тувинского языков несет сугубо функциональное коммуникативное значение и выполняет функцию инструментального языка.

Ключевые слова: языковая ситуация; языковые установки; языковая лояльность; двуязычие; бурятский язык; тувинский язык; Тува; Бурятия

"Статья подготовлена в рамках государственного задания ХІІ.193.1.5. Ментальность монгольских народов в зеркале языка, номер госрегистрации №AAAA-A17-117021310266-8 (“Mentality of the Mongolian peoples in the mirror of language”).

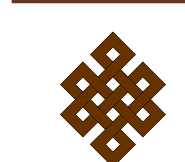

Для циитирования:

Дырхеева Г. А., Цыбенова Ч. С. Языковые установки и языковая лояльность носителей малых языков в условиях национально-русского двуязычия (на примере бурят и тувинцев) [Электронный ресурс] // Новые исследования Тувы. 2020, № 1. URL: https://nit.tuva.asia/nit/article/view/905 (дата обращения: дд.мм.гг.). DOI: 10.25178/nit.2020. 1.5

Дырхеева Галина Александровна - доктор филологических наук, профессор, главный научный сотрудник отдела языкознания Института монголоведения, буддологии и тибетологии СО РАН. Адрес: 670045, Россия, г. Улан-Удэ, ул. Сахьяновой, д. 6. Тел.: +7 (301-2) 43-35-51. Эл. адрес: an5dag1@mail.ru ORCID ID: 0000-0003-3477-6280

Цыбенова Чечек Сергеевна - кандидат филологических наук, младший научный сотрудник отдела языкознания Института монголоведения, буддологии и тибетологии СО РАН. Адрес: 670045, Россия, г. Улан-Удэ, ул. Сахьяновой, д. 6. Тел.: +7 (301-2) 43-35-51. Эл. адрес: tschechek@mail.ru ORCID ID: 0000-0002-7789-1492

Dyrkheeva Galina Aleksandrovna, Doctor of Philology, Chief Research Fellow, Department of Linguistics, Institute for Mongolian, Buddhist and Tibetan Studies, Siberian Branch, Russian Academy of Sciences. Postal address: 6 Sakhianova Str., 670047 Ulan-Ude, Russian Federation. Tel.: +7(301-2) 43-35-51.E-mail: an5dag1@mail.ru

Tsybenova Chechek Sergeevna, Candidate of Philology, Junior Researcher, Department of Linguistics, Institute for Mongolian, Buddhist and Tibetan Studies, Siberian Branch, Russian Academy of Sciences. Postal address: 6 Sakhianova Str., 670047 Ulan-Ude, Russian Federation. Tel.: +7(301-2) 43-35-51.E-mail: tschechek@mail.ru 


\title{
Language attitudes and language loyalty of minor language speakers under the conditions of national-Russian bilingualism: the case of Buryats and Tuvans"
}

\author{
Galina A. Dyrkheeva, Chechek S. Tsybenova \\ Institute for Mongolian, Buddhist and Tibetan Studies, SB RAS, Russian Federation
}

\begin{abstract}
The article examines the language attitudes and orientations of modern speakers of Buryat and Tuvan languages in Russia (more specifically, in the Republic of Buryatia and the Republic of Tuva). The need for professional and cultural integration of minor language speakers into all-Russian and global space today gradually leads to the transformation of their ethno-linguistic consciousness.

For its empirical base, the study relies on the results of complex sociolinguistic surveys conducted in Buryatia (1999-2000) and in Tuva (2009-2010) according to identical methodology. However, a comparative analysis of language situations in these regions has been carried out for the first time.

Examining the evaluation characteristics of language situations in both regions revealed that the Russian language, which is demographically and functionally dominant, has a huge impact on language loyalty and language attitudes. Under the conditions of national-Russian bilingualism, speakers of minor languages choose the strategy of symbolization of the native language. This fact indirectly confirms the transformation of the linguistic consciousness of small nations. This strategy must have been triggered by adaptation mechanisms, which in their turn have been set in motion by new socio-economic conditions, informatization, and technologization of modern society. The strategy of symbolization indicates that the Russian language for the majority of Buryats and Tuvans has only functional communicative value and carries out the function of an instrumental language.
\end{abstract}

Keywords: language situation; language attitudes; language loyalty; bilingualism; Buryat language; Tuvan language; Tuva; Buryatia

"The article was prepared within the government assignment (project XII.193.1.5 'Mentality of Mongolic Peoples in the Mirror of Language', reg. No.AAAA-A17-117021310266-8).

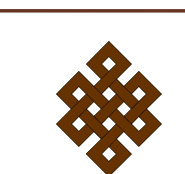

For citation:

Dyrkheeva G. A. and Tsybenova Ch. S. TLanguage attitudes and language loyalty of minor language speakers under the conditions of national-Russian bilingualism: the case of Buryats and Tuvans. The New Research of Tuva, 2020, no. 1 [online] Available at: https://nit.tuva.asia/nit/article/view/905 (access date ... ). DOI: 10.25178/nit.2020.1.5

\section{Введение}

Современная эпоха, процессы модернизации и глобализации, охватившие практически весь мир, привели к тому, что в многонациональных обществах остро встала проблема сосуществования языков. Учеными отмечается, что в любой стране с этническим и языковым многообразием существуют две тенденции. Одна из них связана с необходимостью языкового единения государства, а другая стремлением разных языковых общностей сохранить и развивать свой национальный язык и национальную культуру (Функционирование языков ..., 2008: 6). Актуальной указанная проблема является и для языковой ситуации в России, на территории которой, по подсчетам специалистов, функционируют 92 языка коренных народов.

С точки зрения социолингвистической типологии общим для большинства национальных субъектов РФ является софункционирование нескольких типов языков в едином коммуникативном пространстве и их функциональная неравнозначность: русский язык, выполняющий максимальные общественные функции, региональные титульные языки с ограниченными функциями и локальные языки этнических групп с минимальными функциональными возможностями. При этом языковая ситуация в российских регионах имеет свои особенности, определяющие уникальность и своеобразие каждого из них.

В этом плане показательными можно назвать языковые ситуации (ЯС) в Бурятии и Туве. Несмотря на разные культурно-исторические и социальные условия функционирования бурятского и тувинского языков, мы наблюдаем одинаковые тенденции, связанные с узостью сфер их функционирования, ухудшением языковой компетенции национальной молодежи, сокращением количества носителей 
языков. В основе указанных процессов лежат и объективные, и субъективные факторы, которые способствуют смене языковых установок, трансформации системы традиционных ценностей, языкового сознания. В связи с этим, в рамках настоящей статьи сделана попытка анализа особенностей языковой лояльности и языковых установок бурят и тувинцев по отношению к родным (бурятскому и тувинскому) и русскому языкам.

\section{Материал исследования}

Для описания языковых установок и степени языковой лояльности носителей бурятского и тувинского языков в статье использованы результаты массовых опросов, проведенных авторами в разное время. Языковая ситуация в Республике Бурятия (РБ) активно исследуется с середины ХХ в. Ее мониторинг на базе Института монголоведения, буддологии и тибетологии СО РАН (ИМБТ) ведется с 1989 г. В частности, уже проведено несколько массовых обследований в 1989-1990, 1999-2000 и 2008-2009 гг. Данные исследования были проведены на территории этнографической Бурятии (Республика Бурятия, Усть-Ордынский Бурятский округ Иркутской области, Агинский Бурятский округ Забайкальского края) (Дырхеева, Будаев, Бажеева, 1999; Дырхеева, 2002, 2011). В 2005-2006 гг. полевой материал социолингвистами ИМБт был собран среди бурятского населения Китая и Монголии (Дырхеева и др., 2009). Таким образом, полученные данные по различным районам бытования бурятского языка, по его диалектам позволяют проводить постоянный мониторинг ЯС в Бурятии, сопоставлять их по разным показателям, анализировать различные группы населения, выявлять особенности изменения ситуации.

Социолингвистическое обследование по Республике Тыва (РТ) было проведено по этой же методике в период с 2009 по 2010 гг. (Цыбенова,2017). Сферы функционирования тувинского языка, уровень языковой компетенции его носителей, различные аспекты языковой ситуации как в Туве, так и в других местах постоянного проживания тувинцев изучались в разные годы многими специалистами (Анайбан, 1996; Бавуу-Сюрюн, 2010; Боргоякова, 2002; Вэй Цень Фан, 2016; Журавель, 2015). Среди них можно выделить недавние исследования, проведенные сотрудниками Тувинского института гуманитарных и прикладных социально-экономических исследований. Например, в рамках 80-летнего юбилея тувинской письменности в 2010 г. ими было проведено социологическое исследование городского населения Тувы «Тувинский язык и письменность в общественном мнении кызылчан». Исследование получило широкий общественный резонанс, результаты его были опубликованы в средствах массовой информации ${ }^{1}$ В 2016 г. сотрудниками института было проведено очередное массовое обследование населения Тувы (Серээдар,2018). Однако проведенные исследования, к сожалению, преследуют разные цели и содержат разную методику. В связи с этим сравнение полученных данных, проведение мониторинга, подобно тому, что было в отношении бурятского языка, выявление динамики развития тувинского языка представляется пока невозможным из-за несводимости и недостаточности сведений.

Целью настоящей статьи является анализ результатов исследования языковых установок и степени языковой лояльности бурят и тувинцев, по результатам обследований, проведенных авторами в 1999-2000-х гг. по Бурятии и в 2009-2010-х гг. - по Туве. Несмотря на то, что выборка, цели и задачи опросов имели свои особенности, теоретические подходы, также берутся два различных отрезка времени -методология исследований оставалась единой и ключевые вопросы относительно языковой компетенции и языковой лояльности респондентов не менялись (Дырхеева, 2002; Цыбенова, 2017). Поэтому полученные результаты позволяют сравнить некоторые данные. Таким образом, в работе впервые предпринята попытка сравнительного анализа функционального состояния бурятского и тувинского языков по отдельным показателям, а именно степени языковой лояльности, характеру и направлению языковых ориентаций носителей указанных языков. Общие сведения выборок представлены в следующей таблице (табл. 1).

${ }^{1}$ Кан, В. С. (2010) Тувинский язык и письменность в общественном мнении кызылчан [Электронный ресурс] // Плюс Информ. 2 августа URL: http://plusinform.ru/main/1669-sotsiologicheskie-issledovaniya.html (дата обращения: 05.06.2019). 
Таблица 1. Основные демографические сведения выборки исследований Table 1. Key demographics of the research sample

\begin{tabular}{|c|c|c|c|c|c|}
\hline Регион & Годы & $\begin{array}{c}\text { Всего опрошено, } \\
\text { чел. }\end{array}$ & \multicolumn{2}{|c|}{$\begin{array}{c}\text { муж. жен. } \\
\%\end{array}$} & $\begin{array}{c}\text { Родились в городе } \\
\text { / селе, \% }\end{array}$ \\
\hline Республика Бурятия & $1999-2000$ & 1505 & 40,5 & 59,5 & $38,9 / 60,9$ \\
\hline Республика Тыва & $2009-2010$ & 637 & 47,7 & 52,3 & $28,7 / 71,0$ \\
\hline
\end{tabular}

Отметим, что временной разрыв между проведенными исследованиями существенную разницу в показателях не вносит. В науке известно, что языковые процессы меняются гораздо медленнее, чем социальные и культурные. С точки зрения диахронической социолингвистики, заметить те или иные перемены в языке можно на достаточно значительных временных отрезках - не менее чем в два-три десятилетия (Беликов, Крысин, 2001: 323). Проводимые сотрудниками ИМБт регулярные исследования свидетельствуют о том, что различные показатели состояния языка (признание языка родным, формам и степени его владения, сферам его использования) в среднем меняются на 3-10\% за десятилетие (Дырхеева, 2002, 2011).

\section{Общая социолингвистическая характеристика}

Языковая ситуация как в Бурятии, так и в Туве по составу языков-компонентов характеризуется как многокомпонентная: русский язык - государственный язык, язык межнационального общения; бурятский и тувинский языки - основные языки-компоненты, имеющие государственный статус в своих республиках. По функциональной нагрузке ЯС в регионах является неравновесной: русский язык - мажоритарный, обслуживает практически все сферы общения; бурятский и тувинский языки миноритарные, выполняющие ограниченную функциональную нагрузку.

Необходимо отметить, что объем общественных функций, выполняемых тувинским и бурятским языками, немного различаются. Это связано с разной демографической мощностью (общая доля носителей языка в структуре численности всего населения региона) указанных языков (табл. 2).

Таблица 2. Динамика численности наиболее многочисленных национальностей Бурятии и Тувы по итогам переписей населения, чел.

Table 2. Dynamics of the most numerous nationalities of Buryatia and Tuva according to the results of censuses, people.

\begin{tabular}{|c|c|c|c|c|}
\hline \multirow{2}{*}{ Переписи населения } & \multicolumn{2}{|c|}{ Республика Бурятия } & \multicolumn{2}{|c|}{ Республика Тыва } \\
\cline { 2 - 5 } & буряты & русские & тувинцы & русские \\
\hline 1989 г. & 249525 & 726165 & 198448 & 98831 \\
\hline 2002 г. & 272910 & 665512 & 235313 & 61442 \\
\hline 2010 г. & 286839 & 630783 & 249299 & 49434 \\
\hline
\end{tabular}

Кроме этого, функциональное состояние бурятского и тувинского языков обусловлены внешними, экстралингвистическими факторами, связанными с географическим расположением регионов, с историческими, социально-культурными и другими особенностями развития бурят и тувинцев. Наиболее существенное влияние на функциональное состояние бурятского языка оказывают территориальная дисперсность бурят (они проживают на территории трех административных образований: Республика Бурятия, Усть-Ордынский округ Иркутской области, Агинский округ Забайкальского края), значительные междиалектные расхождения, транспортная доступность Бурятии (проходимость территории республики способствует ее заселению различными народами), многолетняя история бурятско-русских этноязыковых контактов (с середины XVII - начале XVIII в.). Дисперсность проживания бурят, их активное общение в ходе совместной деятельности с русским населением, составляющим большинство в республике, привели к ослаблению культурно-языковой устойчивости современных бурят, утрате некоторых элементов этнической самобытности, к постепенной потере родного языка. 
Среди факторов, положительно влияющих на состояние бурятского языка, следует назвать увеличение численности бурятского населения во всех трех административных образованиях, восстановление преподавания на бурятском языке и обучение бурятскому языку, рост национального и религиозного самосознания бурят. Наблюдаются положительные изменения в отношении русского населения республики по отношению к изучению бурятского языка в школе. Следует отметить установившийся в последнее время активный туристический поток с Монголией, жители которого являются носителями родственного языка. В этом случае между бурятами и монголами нередко возникают ситуации, когда бурятский язык используется как средство межнационального общения. Данная ниша создает благоприятные условия для дальнейшего развития и популяризации бурятского языка и культуры.

Языковую ситуацию в Туве определяют его труднодоступность и отдаленность от основных транспортных путей (до ближайшей железнодорожной станции в Абакане 410 км), компактное расселение основной части тувинцев на одной территории, более позднее вхождение Тувы в состав СССР (в 1944 г.). Большую роль в укреплении и становлении общественных функций и стилистического разнообразия тувинского литературного языка сыграло его бытование в период Тувинской Народной Республики (1921-1944 гг.). Эти факторы во многом предопределили численное преобладание тувинцев по отношению к другим национальностям республики и создали основу для успешного функционирования тувинского языка в различных коммуникативных сферах.

Вместе с тем относительно однородный (тувинский) тип этнической среды, сложившийся в постперестроечные годыв Туве, привел к ухудшению владением большинством населения русским языком. Вследствие такого положения, а также образовательной политики государства в настоящее время наблюдается искусственное нарушение межпоколенной передачи тувинского языка: многими родителями-тувинцами сознательно практикуется использование русского языка как языка межличностного общения со своими детьми, многие из них намеренно отдают неподготовленных детей с ранних лет в классы с русским языком обучения. Общение на русском постепенно становится привычкой даже в этнически гомогенных браках, в сельской местности, среди молодежи. Ситуация с тувинским языком ухудшается быстрыми темпами, чему способствуют и постепенное распространение сети Интернет, доступность коммуникационного пространства на русском языке (телевидение, радио, пресса, медиа и т. д.), вовлеченность молодежи в различные социальные сети и т. п. Частично данная проблема рассматривалась в публикации Ч. С. Цыбеновой (Цыбенова, 2019).

В силу указанных выше факторов функциональная мощность бурятского и тувинского языков имеет как схожие, так и отличительные черты. Результаты проведенных социолингвистических опросов в целом показывают одинаковую функциональную дистрибуцию исследуемых языков по различным сферам: в сферах организованного общения доминирует преимущественно русский язык, в сферах неорганизованного общения - бурятский и тувинский языки. Как видно из табл. 3, в разных сферах общения тувинский язык используется пока интенсивнее, что обусловлено относительно однородным этническим составов населения Тувы.

Таблица 3. Использование языков в различных сферах общения, в \% Table 3. Use of languages in various domains of communication, in $\%$

\begin{tabular}{|l|c|c|c|c|}
\hline \multirow{2}{*}{\multicolumn{2}{|c|}{ Сферы общения }} & \multicolumn{2}{c|}{ Республика Бурятия } & \multicolumn{2}{c|}{ Республика Тыва } \\
\cline { 2 - 5 } & бурятский & русский & тувинский & русский \\
\hline Дома, в семье & 38,2 & 50,5 & 91,3 & 8,7 \\
\hline На работе/учебе & 14,7 & 22,6 & 52,8 & 50,1 \\
\hline В государственных учреждениях & - & - & 31,3 & 53,4 \\
\hline С родственниками & 36,4 & 48,9 & 92,3 & 6,0 \\
\hline С друзьями & 19,5 & 64,7 & 79,5 & 13,1 \\
\hline В культовых местах & - & - & 92,6 & 2,8 \\
\hline $\begin{array}{l}\text { В общественных местах (в магазине, } \\
\text { транспорте, на улице) }\end{array}$ & 7,2 & 80,7 & 55,7 & 33,5 \\
\hline
\end{tabular}




\begin{tabular}{|l|c|c|c|c|}
\hline При чтении художественной литературы & 3,3 & 79,4 & 31,0 & 60,2 \\
\hline -специальной литературы & 2,1 & 70,6 & 11,7 & 59,8 \\
\hline -периодики & 1,5 & 75,6 & 29,3 & 67,9 \\
\hline $\begin{array}{l}\text { При просмотре ТВ и прослушивании } \\
\text { радио }\end{array}$ & 2,4 & 81,5 & 24,9 & 83,6 \\
\hline
\end{tabular}

\section{Степень языковой лояльности}

Наиболее показательным оценочным признаком, поддающимся статистическому измерению, считается степень языковой лояльности, т.е. признание родным своего этнического языка. По мнению специалистов, у каждого народа существует свой набор оценочных признаков. Например, выбор языка в качестве средства общения и языка обучения, защита языка правовыми актами, стремление к расширению социальных функций родного языка, изучение и сохранение культурного наследства на своем языке, передача языка подрастающим поколениям (Кондрашкина, 2010: 198).

Уровень языковой лояльности носителей бурятского и тувинского языков по результатам опросов выглядит следующим образом (табл. 4).

Таблица 4. Родной язык респондентов

Table 4. Native language of respondents

\begin{tabular}{|c|c|c|c|}
\hline \multirow{2}{*}{ Регион } & $\begin{array}{c}\text { Всего } \\
\text { опрошено, чел. }\end{array}$ & Язык & $\begin{array}{c}\text { \% от общего числа } \\
\text { опрошенных }\end{array}$ \\
\hline \multirow{2}{*}{ Республика Бурятия } & \multirow{2}{*}{1505} & бурятский & 67,7 \\
\cline { 3 - 4 } & & русский & 9,2 \\
\cline { 3 - 4 } & \multirow{2}{*}{637} & оба языка & 2,4 \\
\hline \multirow{2}{*}{ Республика Тыва } & \multirow{2}{*}{ тувинский } & 97,8 \\
\cline { 3 - 4 } & & русский & 1,4 \\
\hline
\end{tabular}

Следует отметить, что понятие «родной язык» у большинства людей ассоциируется только лишь с национальной принадлежностью, многими из них не подразумевается реальное владение самим языком. В нашем случае респонденты в Бурятии указывали родным бурятский язык, в Туветувинский. Хотя на самом деле преимущественным языком повседневного общения у них был русский. Поэтому многие специалисты отмечают, что национальное самосознание более устойчивый компонент в структуре личности, чем национальный язык, и они не всегда совпадают.

Степень языковой лояльности тесно взаимосвязана с уровнем владения языками. Уровень языковой компетенции бурят и тувинцев во владении родными и русским языками по результатам опросов также имеет свои особенности (табл. 5).

Таблица 5. Формы и степень владения языками, в \% Table 5. Forms and degrees of language proficiency, in $\%$

\begin{tabular}{|c|c|c|c|c|c|c|c|c|c|}
\hline \multicolumn{10}{|c|}{ Республика Бурятия } \\
\hline \multirow{2}{*}{ формы } & \multicolumn{5}{|c|}{ бурятский язык } & \multicolumn{4}{|c|}{ русский язык } \\
\hline & $\begin{array}{c}\text { очень } \\
\text { хорошо }\end{array}$ & хор. & удовл. & плохо & $\begin{array}{c}\text { не } \\
\text { владею }\end{array}$ & $\begin{array}{c}\text { очень } \\
\text { хорошо }\end{array}$ & хор. & удовл. & плохо \\
\hline понимаю & 23,4 & 37,5 & 19,7 & 13,8 & 4,9 & 65,6 & 29,6 & 3,8 & 0,6 \\
\hline говорю & 13,7 & 26,8 & 22,2 & 24,1 & 12,1 & 47,6 & 37,4 & 12,0 & 1,8 \\
\hline читаю & 11,5 & 28,2 & 23,2 & 22,2 & 13,9 & 53,5 & 39,9 & 4,6 & 0,9 \\
\hline пишу & 8,9 & 23,0 & 22,2 & 23,0 & 21,6 & 37,7 & 45,0 & 14,4 & 1,6 \\
\hline
\end{tabular}




\begin{tabular}{|c|c|c|c|c|c|c|c|c|c|}
\hline \multicolumn{10}{|c|}{ Республика Тыва } \\
\hline степень & \multicolumn{5}{|c|}{ тувинский язык } & \multicolumn{4}{|c|}{ русский язык } \\
\hline & $\begin{array}{c}\text { очень } \\
\text { хорошо }\end{array}$ & хор. & удовл. & плохо & $\begin{array}{c}\text { не } \\
\text { владею }\end{array}$ & $\begin{array}{c}\text { очень } \\
\text { хорошо }\end{array}$ & хор. & удовл. & плохо \\
\hline понимаю & 57,6 & 39,5 & 2,5 & 0,3 & - & 36,2 & 52,8 & 9,9 & 1,1 \\
\hline говорю & 47,9 & 46,8 & 4,9 & 0,5 & - & 20,6 & 55,4 & 20,8 & 3,1 \\
\hline читаю & 49,6 & 39,2 & 8,7 & 2,4 & 0,2 & 32,3 & 55,7 & 10,1 & 1,9 \\
\hline пишу & 43,3 & 43,0 & 9,4 & 3,8 & 0,5 & 26,1 & 55,1 & 16,2 & 2,5 \\
\hline
\end{tabular}

Из представленной таблицы видно, что никто из респондентов по обоим массивам не указали параметр «не владею» для русского языка, отрицательные значения также минимальны. Соответственно, можно утверждать, что русским языком и буряты, и тувинцы владеют достаточно хорошо - в письме, чтении, в разговорной форме и понимании. При этом буряты формами русского языка владеют лучше, чем родного бурятского. Тувинцы же формами русского языка владеют немного хуже, чем буряты.

По бурятскому языку данные распределились в основном между тремя показателями: «хорошо», «удовлетворительно» и «плохо». По тувинскому языку заметно преобладание в сторону оценки «очень хорошо». В целом указанные значения коррелируют с уровнем языковой лояльности респондентов: средние значения характерны для бурят, более высокие для тувинцев.

\section{Языковые установки}

Субъективные факторы выбора бурятского языка и отношение к нему целенаправленно стали исследоваться с 2000-х гг. В основном они выявлялись прямыми методами. Так, в анкету были включены ряд вопросов, направленных на выявление отношения респондентов к образовательному процессу на бурятском языке: «Удовлетворены ли Вы процессом обучения на бурятском языке, если Вы изучаете (или изучали) его в школе (техникуме, институте)?»; «Хотели бы Вы знать его в совершенстве?»; «Почему Вы изучаете/изучали бурятский язык?»

Согласно результатам, преподавание бурятского языка в школах республики положительно оценили $51,8 \%$ респондентов, отрицательно - 25\%. Отрицательные ответы на серию указанных вопросов были объяснены либо нежеланием отвечать на вопрос, либо отсутствием обучения. Кроме того, многие респонденты посчитали, что они знают язык Основным мотивом изучения бурятского языка чаще всего указывалось то, что он является для них родным языком (71,3\%) (табл. 6).

Таблица 6. «Почему Вы изучаете (изучали) бурятский язык?», в \% Table 6. «Why do (did) you study the Buryat language?», in \%

\begin{tabular}{|l|c|}
\hline Считаю его родным & 71,3 \\
\hline Его преподавали & 21,3 \\
\hline Мне нравится изучать языки & 9,8 \\
\hline Заставляют изучать родители & 4,0 \\
\hline Он помогает в общении с друзьями, родственниками & 21,3 \\
\hline Он позволяет знакомиться с достижениями бур. нац. культуры & 31,2 \\
\hline Другие причины & 1,6 \\
\hline Нет ответа & 6,9 \\
\hline
\end{tabular}

Основными причинами нежелания или невозможности изучать бурятский язык респонденты указывали такие ответы, как«испытываю трудности в изучении языков»и «считаю, что он не пригодится в жизни». При анализе ответов был выявлен своеобразный перенос фокуса внимания с себя на детей, на других людей. Например, на вопрос «Должен ли Президент Бурятии знать бурятский язык?», 
подавляющее большинство 92,6\% ответили положительно. Или более 90\% респондентов хотели бы, чтобы их дети знали бурятский язык.

Полученные результаты выявили противоречие между собственным нежеланием и желанием того, чтобы другие люди знали и владели языком. На данное противоречие указывают и другие исследователи. Например, Э. В. Хилханова связывает ее со стратегией идеализации и символизации титульного языка и называет эту стратегию «...ностальгией по той утерянной цельной этнической идентичности наших предков, когда в ней присутствовали все компоненты, в том числе и языковой. Ностальгия тесно связана с идеализацией языка своего народа и отнюдь не влечет за собой реальных мер по его овладению» (Хилханова, 2007: 92).

Необходимо отметить, что результаты исследований проведенных на материале многих титульных языков РФ, также подтверждают наличие фрагментации (множественности) этничности современного поколения носителей малых языков.Например, в Республике Татарстан в 2012 г. 54\% опрошенных татар (из 1590 респондентов) считали, что можно быть татарином, не владея татарским языком. Татарские исследователи отмечают, что татарско-русское двуязычие среди татар сегодня широко распространено и все больше татар готовы признать и русский, и татарский языки родными, «вопреки принятому правилу о признании одного языка родным» (цит. по: Степанова, 2015: 177). Якутские исследователи также отмечают толерантное отношение к подобному явлению. Среди якутов на вопрос «Как Вы относитесь к людям своей национальности, не владеющим родным языком?» положительно ответили 39,4\% опрошенных (Иванова, 2012: 26).

Ряд оценочных вопросов был включен и в социолингвистический опросник по Туве. Анализ ответов выявил две тенденции: направленную на владение русским языком и связанную с символизацией тувинского языка. В ходе опроса многие респонденты отмечали, что «Если не знать тувинского языка, отдалишься от своего народа, если не знать русского, не увидишь светлого будущего» (досл. перевод от «Тыва дылды билбес болза төрээн чондан хоорлур апаар, орус дылды билбес болза от дег чырык көрбес anаaр»). Приведенное высказывание является ярким примером того, какую роль выполняет сегодня русский язык в жизни современного тувинского общества. Так, ответы на вопрос о необходимости владения языками показали, что значение параметра «очень важно» несколько выше у русского языка ( $78,0 \%)$, чем у тувинского (72,8\%). Ответы на вопрос о том, какие языки необходимо изучать их детям, также выявили доминирующее положение русского языка $(86,6 \%)$, затем следуют тувинский $(73,7 \%)$ и иностранный $(66,8 \%)$ языки.

Значение тувинского языка для будущих поколений выяснялось вопросом «Хотели бы Bы, чтобы Ваши дети знали тувинский язык?» Большинство респондентов ответили положительно - 95,0\%. При этом была выявлена положительная корреляция по параметру «возраст», т. е. чем моложе носители языка, тем ниже показатели по параметру «тувинский язык» (табл. 7).

Таблица 7. Значение тувинского языка для детей в зависимости от возраста, в \% Table 7. Value of the Tuvan language for children, age-correlated, in \%

\begin{tabular}{|c|c|c|c|}
\hline \multirow{2}{*}{ Поколения } & \multicolumn{3}{|c|}{ Показатели } \\
\cline { 2 - 4 } & да & нет & безразлично \\
\hline старшее & 96,9 & 1,0 & 1,0 \\
\hline среднее & 95,8 & 0,8 & 1,1 \\
\hline младшее & 92,3 & 1,6 & 4,4 \\
\hline
\end{tabular}

Эти данные позволяют утверждать, что младшее поколение больше ориентировано в сторону русского языка, и их ответы можно оценивать как индикаторы языкового сдвига. Отметим, что процессы языкового сдвига пока еще недостаточно изучены. Большинство исследователей утверждают, что языковой сдвиг зарождается в условиях языкового контакта и в зависимости от ситуации его темпы могут быть медленными (сотни лет), быстрыми (три-четыре поколения) или даже катастрофическими, когда переход на доминирующий язык происходит в течение жизни одного поколения (Вахтин, Головко, 2004: 119). Известно, что на начальных этапах сам факт языкового сдвига еще неочевиден и в структуре языка он не проявляется. Характерными для сдвига процессами являются изменение языковой среды, утрата языка в некоторых сферах его употребления, утрата отдельных функций языка, 
следы интерференции, рост удельного веса двуязычных носителей и пр. В условиях сдвига дети также утрачивают мотивацию активно владеть родным (материнским) языком.

Результаты проведенного нами исследования показали, что использование языков зависит от определенной сферы. Несмотря на относительно однородную среду тувинцы, например, в сферах государственного управления, образования русский язык используют гораздо интенсивнее (Цыбенова, 2017). Вероятно это связано с узостью и недостаточной развитостью функциональных стилей тувинского языка, необходимостью ведения деловой документации на русском языке. Кроме того, академический дискурс и какая-либо специальная литература больше распространены и доступны также на русском, нежели на тувинском языке.

В связи с этим, нами проверялась стереотипность взглядов в использовании конкретного языка и позиция респондентов по отношению к использованию тувинского языка в тех коммуникативных сферах, где преимущественно используется русский язык: образование, делопроизводство, общественные места и средства массовой информации. Ответы на данный вопрос выявили положительное отношение к использованию тувинского языка в указанных сферах. При этом большинство респондентов отметили, что в делопроизводстве его применение весьма затруднительно, т. к. может возникнуть «путаница в делах» (табл. 8).

Таблица 8. Отношение респондентов к введению тувинского языка в следующие сферы, в \% Table 8. Respondents' attitudes to the introduction of the Tuvan language into several domains of use, in \%

\begin{tabular}{|l|c|c|c|}
\hline \multirow{2}{*}{\multicolumn{1}{c|}{ Сферы }} & \multicolumn{3}{|c|}{ Отношение } \\
\cline { 2 - 4 } & положительно & отрицательно & безразлично \\
\hline образование & 79,8 & 12,9 & 6,0 \\
\hline делопроизводство & 59,5 & 26,5 & 11,8 \\
\hline общественные места & 68,2 & 13,4 & 15,4 \\
\hline $\begin{array}{l}\text { средства массовой } \\
\text { информации }\end{array}$ & 79,1 & 9,8 & 9,0 \\
\hline
\end{tabular}

Доминирование русского языка в регламентируемых сферах связано и с недостаточной развитостью официально-делового и научного стилей малых языков, в свою очередь такое положение влияет на языковые установки населения, и соответственно заставляет употреблять в данных сферах именно русский язык. В ходе опроса также было выявлено отношение к закону «О языках в Республике Тыва» (принят 31 декабря 2003 г.). Большинство респондентов согласились, что это важный и необходимый акт (77,8\%), необязательность данного закона отметили 3,9\%, а 13,6\% выбрали ответ «безразлично».

Таким образом, тувинцы при выражении отношения к передаче языка своим детям, при оценке степени его востребованности выбирают ту же стратегию, что и носители бурятского языка. При этом тувинский язык в основном рассматривается многими лишь как средство повседневного общения. Более лояльное отношение к русскому языку части тувинцев вероятно объясняется и тем, что в относительно однородной тувиноязычной среде значимость языкового признака ослабляется. Поэтому многие носители не осознают и не замечают степень изменения своей языковой компетенции во владении родным языком. Татарские исследователи также констатируют, что в ситуации этнически гомогенного состава населения роль оппозиции «мы - они» снижается, наблюдается низкая актуализация этнического самосознания (Язык и этнос ..., 2002: 44-45). Результаты исследования по Туве опосредованно отражают и общую картину изменения социокультурных ценностей. Исследования специалистов показывают, что в ценностном мировоззрении современных тувинцев наметилась переориентация на западные жизненные ориентиры: направленность на учебу и получение высшего образования, материальное благосостояние и карьерный рост (Семенова, 2009: 139-140; Leung, 2017).

\section{Заключение}

Оценочные вопросы мы относим к прогностическим вопросам. Направленные на выявление языковых установок они актуализируют этнопсихологические составляющие сознания. Таким образом, 
в ответах отражается установка естественных защитных механизмов, наблюдается символизация языка, несоответствие между реальной/объективной и желаемой ситуацией. В этом случае статус недоминантного языка (бурятского или тувинского), уровень его субъективной жизнеспособности с точки зрения его носителей является довольно высоким. Как известно, любой язык является важнейшим инструментом самоидентификации этноса, наряду с другими культурными факторами (Головко, 2018: 45). Поэтому вполне очевидно, что указанная стратегия основана на подсознательных и инстинктивных процессах, в частности самосохранения.

Усиление символьной функции языка скорее всего обусловлено и адаптационными механизмами, вызванными новыми социально-экономическими условиями, информатизацией, технологизацией современного общества. Психолингвисты пишут, что: «Биологическая природа сознания проявляется в его адаптирующей функции “там, где прекращают действовать врожденные законы поведения, вступает в силу врожденная способность приспосабливаться к условиям окружающей среды”» (цит. по: Шаховский, 2006: 67-68). Таким образом, можно утверждать, что в основе языковых установок заложены несколько механизмов.

В ходе анализа некоторых оценочных параметров ЯС в Бурятии и Туве мы выявили, что на языковую лояльность и языковые установки современных бурят и тувинцев огромное влияние оказывает демографически и функционально доминирующий русский язык. Интеграция носителей малых языков в общероссийское и мировое пространство требует высокого уровня владения русским языком. Выявленная стратегия символизации свидетельствует о том, что пока русский язык для большинства носителей бурятского и тувинского языков несет сугубо функциональное коммуникативное значение, выполняет функцию инструментального языка. В этом случае малые языки, как языки, основанные на культурном и этническом прошлом, имеют пока достаточную субъективную жизнеспособность и обладают высоким уровнем символической мощности. Поэтому сегодня основной задачей следует назвать повышение уровня языкового самосознания национальной молодежи, усиление социальной значимости родного языка.

\section{СПИСОК ЛИТЕРАТУРЫ}

Анайбан, 3. В. (1996) Республика Тува: модель этнологического мониторинга. М. : Ин-т этнологии и антропологии РАН. 96 с.

Бавуу-Сюрюн, М. В. (2010) Тувинский язык на современном этапе: образовательный аспект // Тувинская письменность и вопросы исследования письменностей и письменных памятников России и Центрально-Азиатского региона. Материалы междунар. науч. конф., посвящ. 80-летию тувинской письменности : в 2 ч. / отв. ред. К. А. Бичелдей. Абакан: Хакас. кн. изд-во. Ч. 1. 220с. С. 53-57.

Беликов, В. И., Крысин, Л. П. (2001) Социолингвистика : учебник для вузов. М.: Рос. гос. гуманит. ун-т. 439 с.

Боргоякова, Т. Г. (2002) Развитие социальных функций государственных тюркских языков Республик Южной Сибири : автореф.... дис. д-ра филол. наук. М. 37 с.

Вахтин, Н. Б., Головко, Е. В. (2004) Социолингвистика и социология языка: Учебное пособие. СПб. : ИЦ «Гуманитарная академия» ; Изд-во Европейского университета в Санкт-Петербурге. 336 с.

Вэй Цень Фан (2016) Государственная языковая политика в Республике Тыва в конце XX - начале XXI вв. : дис.... магистра гум. наук [Электронный ресурс] / Гос. ун-т. Чжэнчжи. Тайбэй. 274 c. URL: https:// nccur.lib.nccu.edu.tw/handle/140.119/81442 (дата обращения: 25.01.2017).

Головко, Е. В. (2018) Язык как инструмент этнической самоидентификации // Языковое единство и языковое разнообразие в полиэтническом государстве: Международная конференция (Москва, 14-17 ноября 2018): Доклады и сообщения / отв. ред. А. Н. Биткеева, М. А. Горячева. М. : Языки народов мира. 752 с. С. $44-46$.

Журавель, Т. Н. (2015) Этноязыковая ситуация в Усинской долине Красноярского края : автореф. дис. ... канд. филол. наук. Красноярск. 23 с.

Дырхеева, Г. А (2002) Бурятский язык в условиях двуязычия: проблемы функционирования и перспективы развития. Улан-Удэ: Изд-во БНЦ СО РАН. 187 с.

Дырхеева, Г. А. (2011) Языковая ситуация в Бурятии: двадцать лет спустя // Вестник Бурятского научного центра Сибирского отделения Российской академии наук. № 2. С. 132-138. 
Дырхеева, Г. А., Будаев, Б. Ж., Бажеева, Т. П. (1999) Бурятский язык: современное состояние (социолингвистический аспект). Улан-Удэ: Изд-во БНЦ СО РАН. 142 с.

Дырхеева, Г. А., Даржаева, Н. Б., Бальжинимаева, Ц. Ц., Бороноева, Д. Ц., Сундуева, Д. Б., Аюшеев, Б. Б., Шожоева, Б. Д. (2009) Бурятский язык в поликультурном пространстве (социолингвоисторическое исследование). Улан-Удэ: Изд-во БНЦ СО РАН. 232 с.

Иванова, Н. И. (2012) Современное коммуникативное пространство русского языка в Республике Саха (Якутия): социопсихолингвистический аспект. Новосибирск: Наука. 130 с.

Кондрашкина, Е. А. (2010) Динамика языковой лояльности у финно-угорских народов России // Язык и общество в современной России и других странах: Международная конференция (Москва, 21-24 июня 2010 г.): Доклады и сообщения / отв. ред. В. А. Виноградов, В. Ю. Михальченко. М. : Языки народов мира. 608 с. С. 198-201.

Семенова, Н. Б. (2009) Этнокультуральные особенности самосознания и иерархия жизненных ценностей в структуре мировоззрения тувинской молодежи // Сибирский вестник психиатрии и наркологии. № 2. С. 136-140.

Серээдар, Н. Ч. (2018) Тувинский язык как средство общения тувинцев: проблемы и перспективы [Электронный ресурс] // Новые исследования Тувы. № 1. URL: https://nit.tuva.asia/nit/article/view/752 (дата обращения: 12.10.2018). DOI: 10.25178/nit.2018.1.1

Степанова, А. А. (2015) Языковая ситуация в Республике Татарстан: конфликт или толерантное равновесие? // Вопросы психолингвистики. № 4 (26). С. 169-181.

Хилханова, Э. В. (2007) Факторы коллективного выбора языка и этнокультурная идентичность у современных бурят (дискурс-аналитический подход). Улан-Удэ: Издательско-полиграфический комплекс ФГОУ ВПО ВСГАКИ. 205 с.

Функционирование языков в многонациональном государстве: Россия и Вьетнам (2008) / отв. ред. В. Ю. Михальченко. М.: Советский писатель. 451 с.

Цыбенова, Ч. С. (2017) Современная языковая ситуация в Республике Тыва: социолингвистический аспект / отв. ред. Г. А. Дырхеева. Иркутск : Изд-во «Оттиск». 170 с.

Цыбенова, Ч. С. (2019) Социальная характеристика языковой ситуации в Республике Тыва // Oriental Studies. № 43(3). C. 460-477. DOI: 10.22162/2619-0990-2019-43-3-460-477

Шаховский, В. И. (2006) Эмоции - мотивационная основа человеческого сознания // Вопросы психолингвистики. № 4. С. 64-69.

Язык и этнос на рубеже веков: Этносоциологические очерки о языковой ситуации в Республике Татарстан (2002)/ отв. ред. Р. Н. Мусина.Казань: Магариф. 208 с.

Leung, K. Z. (2017) Contemporary Youth Identity in the Republic of Tuva, Russia [Электронный ресурс] // Новые исследования Тувы. № 3. URL: https://nit.tuva.asia/nit/article/view/725 (дата обращения: 12.10.2019). DOI: $10.25178 /$ nit.2017.3.3

Дата поступления: 17.11.2019 2.

\section{REFERENCES}

Anaiban, Z. V. (1996) Respublika Tuva: model' etnologicheskogo monitoringa [The Republic of Tuva: A model of ethnological monitoring]. Moscow, Institute of ethnology and anthropology of the Russian Academy of Sciences. 96 p. (In Russ.)

Bavuu-Surun, M. V. (2010) Tuvinskii yazyk na sovremennom etape: obrazovatel'nyi aspekt [Tuvan language on modern stage: educational aspect]. In: Tuvinskaya pis'mennost' $i$ voprosy issledovaniya pis'mennostei $i$ pis'mennykh pamyatnikov Rossii i Tsentral'no-Aziatskogo regiona [Tuvan writing and issues of writing and written monuments of Russia and the Central Asian region]. Proceedings of the international conference dedicated to the 80th anniversary of Tuvan written language]. In 2 vols. Executive editor: K. A. Bicheldei. Abakan, Khakass book publishing house. Vol. 1. 220 p. Pp. 53-57. (In Russ.)

Belikov, V. I. and Krysin, L. P. (2001) Sotsiolingvistika [Sociolinguistics]: textbook for universities. Moscow, Russian State Humanitarian University Press. 439 p. (In Russ.)

Borgoyakova, T. G. (2002) Razvitie sotsial'nykh funktsii gosudarstvennykh tyurkskikh yazykov Respublik Yuzhnoi Sibiri [The development of social functions of the state Turkic languages of the republics of Southern Siberia]: Thesis of Diss.... Doctor of Philology. Moscow. 37 p. (In Russ.) 
Vakhtin, N. B. and Golovko, E. V. (2004) Sotsiolingvistika i sotsiologiya yazyka [Sociolinguistics and sociology of language]: A Textbook. Saint-Petersburg, Humanitarian Academy Press, Printing House of European University in Saint-Petersburg. 336 p. (In Russ.)

Wei Tsen Fang (2016) Gosudarstvennayaya yazykovaya politika v Respublike Tyva v kontse XX - nachale XXI vv. [State language policy in the Republic of Tuva]: Diss.... Magister of Humanitarian. State University of Chenji. Taipei. 274 p. [online] Available at: //nccur.lib.nccu.edu.tw/handle/140.119/81442 (accessed: 25.01.2017). (In Russ.)

Golovko, E. V. (2018) Yazyk kak instrument etnicheskoi samoidentifikatsii [Language as ameans of ethnic self-identification]. In: Yazykovoe edinstvo i yazykovoe raznoobrazie $v$ polietnicheskom gosudarstve [Language unity and language diversity in a polyethnic state]: International Conference (Moscow, 14-17 November 2018): Papers and communications / Executive editors: A. N. Bitkeeva and M. A. Goryacheva. Moscow, Languages of the Peoples of the World. 752 p. Pp. 44-46. (In Russ.)

Zhuravel', T. N. (2015) Etnoiazykovaia situatsiia v Usinskoi doline Krasnoiarskogo kraia [Ethnolinguistic Situation in the Usinsk valley, Krasnoiarsk krai]: Thesis of Diss.... Candidate of Philology. Krasnoiarsk. 23 p. (In Russ.).

Dyrkheeva, G. A (2002) Buryatskii yazyk v usloviyakh dvuyazychiya: problemy funktsionirovaniya i perspektivy razvitiya [The Buryat language under the conditions of Bilingualism: Problems of functioning and prospects of development]. Ulan-Ude, Publishing house of the Buryat Scientific Center. 187 p. (In Russ.)

Dyrkheeva, G. A. (2011) Yazykovaya situatsiya v Buryatii: dvadtsat' let spustya [Language situation in Buryatia: 20 years later]. The Bulletin of the Buryat Scientific Center of Siberian Branch of the Russian Academy of Sciences, no. 2, pp. 132-138. (In Russ.)

Dyrkheeva, G. A., Darzhaeva, N. B., Bal'zhinimaeva, C. C., Boronoeva, D. Ts., Sundueva, D. B., Ayusheev, B. B. and Shozhoeva, B. D. (2009) Buryatskii yazyk v polikul'turnom prostrangstve (sociolingvoistoricheskoe issledovanie) [The Buryat language in polycultural area: a sociolingual and historical study]. Ulan-Ude, Publishing house of the Buryat Scientific Center. 232 p. (In Russ.)

Dyrkheeva, G. A., Budaev, B. Zh. and Bazheeva, T. P. (1999) Buryatskii yazyk: sovremennoe sostoyanie (sociolingvisticheskii aspekt) [The Buryat language and its contemporary status: a sociolinguistic aspect]. UlanUde, Publishing house of the Buryat Scientific Center. 142 p. (In Russ.)

Ivanova, N. I. (2012) Sovremennoe kommunikativnoe prostranstvo russkogo yazyka $v$ Respublike Saha (Yakutiya): sociopsiholingvisticheskii aspect [Contemporary communicative area of the Russian language in the Republic of Saha (Yakutia)]. Novosibirsk, Nauka. 130 p. (In Russ.)

Kondrashkina, E. A. (2010) Dinamika yazykovoi loyal'nosti u finno-ugorskih narodov Rossii [The dynamic of language loyalty of Finno-Ugric peoples of Russia]. In: Yazyk $i$ obshchestvo v sovremennoi Rossii $i$ drugikh stranakh [Language and society in modern Russia and other countries]: International Conference (Moscow, June 21-24, 2010): Reports and communications / Executive editors: V. A. Vinogradov, V. Yu. Mikhalchenko. Moscow, The Languages of the Peoples of the World. 608 p. Pp. 198-201. (In Russ.)

Semenova, N. B. (2009) Etnokul'tural'nye osobennosti samosoznaniya i ierarhiya zhiznennykh tsennostei v structure mirovozzreniya tuvinskoi molodezhi [Ethnocultural features of self-consciousness and hierarchy of life values in the structure of the worldview of Tuvan youth]. The Siberian Bulletin of Psychiatry and Narcology, no. 2, pp. 136-140. (In Russ.)

Sereedar, N. Ch. (2018) Tuvinskii yazyk kak sredstvo obshcheniya tuvincev: problemy i perspektivy [Tuvan language as mean of communication among Tuvans: problems and prospects]. The New Research of Tuva, no. 1 [online] Available at://nit.tuva.asia/nit/article/view/752 (accessed: 12.10.2018). DOI: 10.25178/nit.2018.1.1 (In Russ.)

Stepanova, A. A. (2015) Yazykovaya situatsiya v Respublike Tatarstan: konflikt ili tolerantnoe ravnovesie? [Language situation in the Republic of Tatarstan: conflict or tolerant balance?]. Journal of Psycholinguistics, no. 4 (26), pp. 169-181. (In Russ.)

Hilhanova, E. V. (2007) Faktory kollektivnogo vybora yazyka I etnokul'turnaya identichnost' u sovremennyh Buryat (diskurs-analiticheskii podhod) [Factors of collective choice of language and ethnocultural identity among modern Buryats: a discourse-analytical approach]. Ulan-Ude, Univ. press, 205 p. (In Russ.)

Funktsionirovanie yazykov $v$ mnogonatsional'nom gosudarstve: Rossiya $i$ Vietnam [Functioning of languages in multiethnic states: Russia and Vietnam] (2008). Executive editor: V. Yu. Michal'chenko. Moscow, Soviet writer publ. 451 p. (In Russ.). 
Tsybenova, Ch. S. (2017) Sovremennaya yazykovaya situatsiya v Respublike Tyva: sociolingvisticheskii aspekt. [Contemporary language situation in the Republic of Tyva: sociolinguistic aspect]. Executive editor: G. A. Dyrkheeva. Irkutsk, Ottisk publ. 170 p. (In Russ.).

Tsybenova, Ch. S. (2019) Language Situation in the Tuva Republic: Social Characteristics. Oriental Studies, no. 43(3), pp. 460-477. (In Russ.) DOI: 10.22162/2619-0990-2019-43-3-460-477

Shahovskii, V. I. (2006) Emotsii - motivacionnaya osnova chelovecheskogo soznaniya [Emotions as the motivational basis of human consciousness]. Journal of psycholinguistics, no. 4, pp. 64-69. (In Russ.)

Yazyk $i$ etnos na rubezhe vekov: Etnosociologicheskie ocherki o yazykovoi situatsii v Respublike Tatarstan [Language and ethnicity at the turn of the century: Ethnosociological essays on the language situation in the Republic of Tatarstan] (2002). Executive editor: R. N. Musina. Kazan, Magarif publ. 208 p. (In Russ.).

Leung, K. Z. (2017) Contemporary Youth Identity in the Republic of Tuva, Russia. The New Research of Tuva, no. 3 [online] Available at: https://nit.tuva.asia/nit/article/view/725 (access date: 12.10.2019). DOI: 10.25178/ nit.2017.3.3

Submission date: 17.11.2019. 